\title{
PERAN AKTIF WANITA DALAM PENINGKATAN PENDAPATAN RUMAH TANGGA MISKIN: ( STUDI KASUS PADA WANITA BURUH PERKEBUNAN PT ASIAN AGRI di DUSUN PULAU INTAN)
}

\author{
Eva Fitria \\ Sekolah Tinggi Ilmu Ekonomi (STIE) Labuhan Batu, Sumatera Utara \\ e-mail : evafitria09@yahoo.co.id
}

\begin{abstract}
Peran istri tidak hanya sebagai ibu dalam rumah tangga, namun istri juga bisa membantu mencari pengahasilan untuk memenuhi kebutuhan hidup keluarga. Penelitian ini bertujuan untuk mengetahui peran aktif wanita didalam menunjang pendapatan rumah tangga. Jenis penelitian ini merupakan penelitian deskriptif kualitatif. Dalam penelitian ini mendeskripsikan keadaan secara faktual kondisi yang terjadi dilapangan. Hasil penelitian ini menunjukkan bahwa peran aktif wanita sebagai istri-ibu rumah tangga di Dusun Pulau intan, Desa tanjung Harapan sangat besar, karena istri mempunyai dua peran ganda selain beban kerja didalam rumah tangga, juga berperan sebagi pekerja diluar rumah.

Dampak peran aktif wanita (istri-ibu) di Dusun Pulau Intan dalam perekonomiannya sangat tinggi. Mereka bisa memberikan sumbangsih yang besar bagi pendapatan keluarga, walaupun pendapatannya tidak terlalu besar tapi sangat berdampak postif bagi perekonomian keluarga.
\end{abstract}

Kata Kunci: Peran aktif wanita dalam menunjang perekonomian, dampak peran aktf wanita dalam membantu perekonomian rumah tangga

\section{LATAR BELAKANG MASALAH}

Keberhasilan suatu keluarga dalam membentuk sebuah rumah tangga yang sejahtera tidak lepas dari peran seorang ibu yang begitu besar. Baik dalam membimbing dan mendidik anak, mendampingi suami, membantu pekerjaan suami bahkan sebagai tulang pulunggung keluarga dalam mencari nafkah (Darmawani, 2013).

Berdasarkan fakta yang ada dilapangan sering kali kaum perempuan (ibu) menjadi penyelamat perekonomian keluarga. Fakta ini teruatama dapat dilihat pada keluarga-keluarga yang perekonomiannya tergolong rendah, banyak dari kaum perempuan (ibu) yang ikut menjadi pencari nafkah tambahan bagi keluarga yang perekonomiannya kurang mampu. Hal ini bisa terjadi diakarenakan penghasilan suami sebagai pencari nafkah utama tidak dapat mencukupi kebutuhan keluarga. Perempuan ternyata memiliki peranan yang penting dalam mengatasi kemiskinan yang dialami sebagai upaya meningkatan kesejahteraan rumahtangganya (Darmawani, 2015).

Menurut Maria R Sihotang (2011) sebagai perempuan menyatakan persamaan hak sebagai alasan mengapa mereka bekerja. Dalam kerangka emansipasi perempuan sebagaian istri bekerja menganggap behawa peranan mereka dalam pembangunan bangsa dan negara tidaklah optimal kalau hanya sebagai ibu rumah tangga. Secara umum alasan perempuan bekerja adalah untuk membantu ekonomi keluarga. Keadaan perekonomian yang semakin tidak menentu, harga-harga kebutuhan pokok yang semakin meningkat pendapatan keluarga 
yang cenderung tidak meningkat akan berakibat pada terganggunya stabilitas perekonomian keluarga.

Melihat kondisi keluarga miskin pada umumnya seluruh sumber daya manusia disiapkan untuk memperoleh penghasilan sebagai upaya untuk membantu memenuhi kebutuhan sehari-hari. Oleh sebab itu dalam keluarga miskin, mereka berusaha untuk bisa melakukan pekerjaan apapun, terutama yang tidak membutuhkan keahlian tertentu,mudah untuk dimasuki dan tidak membutuhkan modal yang besar.

Wanita pada rumah tangga miskin, rata-rata mempunyai tingkat pendidikan yang relatif rendah karena kondisi ekonomi yang melatarbelakanginya. Wanita ini masuk kepasar kerja dengan tingkat pendidikan rendah dan keterampilan rendah. wanita dengan tingkat pendidikan dan keterampilan yang rendah justru banyak masuk kelapangan kerja, terutama pada sektor informal dengan motivasi menambah pendapatan keluarga.

Didaerah Dusun Pulau Intan, Desa Tanjung Harapan, Kecamatan Pangkatan masyarakatnya mayoritas bekerja sebagai petani, buruh tani dan buruh perkebunan sehingga pendapatan mereka tidak cukup untuk memenuhi kebutuhan sehari-hari. Oleh karenanya dalam memenuhi kebutuhan keluarga tidak hanya dilimpahkan kepada kepala keluarga, melainkan juga para isteri turut membantu terhadap pemenuhan kebutuhan. Dari kondisi tersebut, maka peran isteri dan juga ibu rumah tannga sangat diperlukan guna membantu ekonom keluarga. Perempuan yang bekerja sebagai buruh perkebunan, bertujuan untuk memenuhi kebutuhan hidup rumah tangga mereka. Suami yang bekerja sebagai petani membuat kebutuhan sehari-hari tidak tercukupi.

\section{LANDASAN TEORI}

\section{Teori Kemiskinan}

Secara etimologis, kemiskinan berasal dari kata miskin yan artinya tidak berharta benda dan serba kekurangan. Departemen Sosial dan Badan Pusat Statistik mendefinisikan Kemiskinan dari persepektif kebutuhan dasar. Kemiskinan didefinisikan sebagai ketidakmampuan dalam memenuhi kebutuhan dasar minimal untuk hidup layak ( dalam Tumewang, 2018)

\section{Peran Perempuan}

Perempuan dan Ibu adalah dua sosok yang tidak pernah lepas dari kehidupan kita. Tanpa sosok Ibu kita tidak akan pernah ada di dunia. Bahkan banyak orang-orang hebat yang tidak akan pernah bisa menjadi hebat tanpa didukung dengan sosok wanita hebat dibelakangnya (Darmawani,2013)

Perempuan berperan penting dalam rangka pembentukan kehidupan keluarga yang kokoh sehingga tidak terkena pengaruh negatif dari perubahan serta pencapaian suatu keadaan yang sehat, sejahtera dan bahagia, sehingga mendukung terhadap penciptaan masyarakat yang sejahtera, baik lahir maupun batin. Kemampuan dan potensi yang memadai dari perempuan sebagai istri dan ibu rumahtangga merupakan aspek terpenting dalam menentukan keberhasilan (penunjang utama strategi suksesnya) suatu rumah tangga (terutama masa depan anak/anak generasi penerus). Oleh karena itu, diperlukan inovasi dan adopsi yang berkaitan dengan strategi peningkatan kemampuan dan potensi kaum perempuan, sehingga perempuan dapat berperan optimal di sektor domestik secara professional (Darmawani,2013) 
Menurut Istoyono, 2007 (dalam Rahmah,2014) peranan wanita dalam rumah tangga akan dilihat dalam tiga hal, yaitu:

1. Peranan wanita sebagai tenaga kerja dalam rumah tangga dan sebagai tenaga kerja dalam usaha keluarga. Dalam peran ini wanita mempunyai pekerjaan yang sangat kompleks. Pekerjaan rumah tangga wanita dapat digolongkan pada kegiatan-kegiatan; menyiapkan makanan, mengasuh anak, membersihkan rumah, mencuci pakaian, mencuci perabot rumah tangga.

2. Peranan wanita sebagai pencari nafkah diluar usaha keluarga. Dalam peran ini wanita terdorong untuk bekerja mencari nafkah guna menambah pendapatan keluarga.

3. Peranan wanita pada pengambil keputusan rumah tangga. Dalam peran ini wanita dan pria dalam ikatan suami-istri, masing-masing mempunyai potensi untuk mempengaruhi pasangan dan potensi ini nampak dalam proses pengambilan keputusan dalam berbagai kegiatan yang mempengaruhi kehidupan keluarga.

Menurut Jume'edi (2005) dalam perannya sebagai pencari nafkah keluarga wanita dipengaruhi oleh beberapa faktor-faktor sosial ekonomi, seperti usia, pendidikan, jumlah tanggungan keluarga, dan pendapatan anggota rumah tangga yang lainnya.

1. Usia Wanita

Suparyo Hugeng (2011) berpendapat usia wanita diduga sangat bepengaruh terhadap aktivitas mereka dalam bekerja sehari-hari.

2. Jumlah Tanggungan Keluarga

Jumlah tanggungan keluarga akan mempengaruhi curahan kerja ibu rumah tangga yang secara tidak langsung memberikan pengaruh terhadap perannya dalam mencari nafkah. Jumlah anggota keluarga dan komposisinya memepengaruhi curahan waktu kerja rumah tangga untuk mendapatkan penghasilan yang lebih tinggi guna memenuhi kebutuhan keluarganya yang semakin meningkat

3. Pendapatan Rumah Tangga

Didalam keluarga pendapatan suami terkadang tidak cukup untuk memenuhi kebutuhan keluarganya sehingga anggota keluarga yang lain seperti istri dan anak-anaknya ikut dilibatkan dalam kegiatan mencari nafkah.

\section{Pekerja Wanita dan Motivasi Kerja}

Wanita memiliki kontribusi besar dalam membantu perekonomian keluarga, khususnya keluarga yang perekonomiannya tergolong rendah. Wanita harus bekerja diluar rumah untuk menambah pendapatan rumah tangga yang dirasakan tidak cukup. Hasil penelitian yang dilakukan Mariun (2004) menunjukkan dari 53,44 persen perempuan yang bekerja, 72,79\% adalah pekerja tetap. Artinya perempuan mempunyai kepastian dalam memperoleh pendapatan. Yuniarti dan Haryanto (2005) pendapatan para pekerja wanita pada industri sandang mempunyai kontribusi yang signifikan terhadap peningkatan pendapatan keluarga. Kontribusi perempuan dapat dikatakan sebagai penopang bagi rumah tangga miskin untuk memenuhi kebutuhan dasar sehari-hari. 


\section{METODOLOGI PENELITIAN}

\section{Jenis penelitian}

Jenis penelitian yang digunakan adalah penelitian deskriptif yaitu studi untuk menemukan fakta dengan interprestasi yang tepat. Penelitian ini dipergunakan untuk mendeskripsikan tentang peran perempuan dalam membantu perekonomian keluarga di di Dusun Pulau Intan.

\section{Jenis Data}

Jenis data dalam penelitian ini adalah data primer yang berupa data pekerja wanita sebagai buruh perkebunan di Dusun Pulau Intan, waktu bekerja, kegiatan sosial kemasyarakatan, pendapatan dari hasil bekerja sebagai buruh perkebunan, pendapatan seluruh keluarga

\section{Metode Analisis}

Metode analasis kualitatif adalah suatu metode penelitian untuk menghasilkan data dekskriptif berupa kata-kata tertulis maupun lisan dari informan yang diwawancari.

\section{Teknik Pengumpulan Data}

a. Pengamatan (observasi)

Penulis menggunakan beberapa teknik pengumpulan data yaitu teknik pengamatan. Pengamatan yang terlibat. berperan serta atau pengamatan yang terlibat. Pengamatan terlibat adalah pengamatan yang dilakukan sambil ikut berperan serta dalam kehidupan yang orang yang diteliti. Becker et.al dalam (Mulyana,2001:162)

b. Wawancara

Pada penelitian ini penulis melakukan wawancara mendalam dan tidak terstruktur artinya wawancara dilakukan tidak disusun sedemikian rupa tetapi dilakukan secara kualitatif dan berlangsung secara alami dan fokus pada persoalan penelitian.

c. Dokumentasi

Dokumen merupakan catatan peristiwa yang sudah lalu. Dokumen bisa berbentuk tulisan seperti catatan harian, sejarah kehidupan, biografi, cerita, peraturan dan kebijakan. Berbentuk gambar, misalnya foto, gambar hidup dan sketsa. Atau karya karya monumental dari seseorang misalnya film, atung, gambar, dan lain-lain (Sugiyono, 2011:240)

\section{HASIL PENELITIAN DAN PEMBAHASAN}

Dusun Pulau Intan adalah adalah salah satu Dusun yang berada di Desa Tanjung Harapan Kabupaten Labuhanbatu, Provinsi Sumatera Utara, dimana mayoritas penduduknya adalah bekerja sebagai petani, buruh tani dan buruh perkebunan. Perkebunan ini adalah PT ASIAN AGRI tetapi biasanya masyarakat desa Tanjung Harapan Menyebutnya PT RSK.

Berdasarkan dari hasil pengamatan peneliti jika dilihat dari latar belakang sosial ekonomi masyarakat di Dusun Pulau Intan sekitar 90\% adalah masyarakat yang tidak memiliki pekerjaan tetap, mereka hanya bertani, buruh tani, buruh perkebunan sehingga pendapatan mereka juga tergolong sangat rendah. Walaupun banyak masyarakat Dusun Pulau Intan 
memiliki lahan pertanian kepala sawit, namun lahan tersebut luasnya sangat lah kecil, jika dilihat dari hasil panennya tidak mencukupi untuk memenuhi kebutuhan hidup sehari-hari, apa lagi pada saat harga kelapa sawit menurun sangat berdampak pada perekonomian masyarakat. Dengan kondisi tersebut, banyak masyarakat yang menjadi buruh tani dan buruh perkebunan. Sedangkan para wanita di Dusun Pulau Intan banyak membantu suami mereka untuk menambah perekonomian keluarga, mereka tidak hanya diam dirumah mengurusi ranah domestiknya seperti memasak, mencuci , mengurus anak, melayani suami akan tetapi mereka mencari kegiatan yang mendatangkan pendapatan. Dari pengamatan peneliti, banyak para wanita di Dusun Pulau Intan yang berjualan, menanam sayur, mencari sapu lidi, mencari buah sawit (buah sawit yang sudah lepas dari janjangannya) dilahan milik orang lain yang sudah seizin dari pemiliknya, dan banyak juga menjadi buruh perkebunan di PT ASIAN AGRI.

\section{Peran Wanita (Istri-Ibu Rumah Tangga)}

Peran istri tidak hanya sebagai ibu dalam rumah tangga, namun istri juga bisa membantu mencari pengahasilan bagi kebutuhan hidup keluarga. Dari hasil pengamatan dan wawancara dengan para istri (ibu-ibu) petani di Dusun Pulau Intan, mereka tidak hanya mengurusi pekerjaan rumah tangga saja (domestik), seperti: mencuci, memasak, melayani suami, mengurus anak, membersihkan rumah, dll. Tetapi juga membantu memenuhi kebutuhan keluarga, dengan bekerja. Hal ini sesuai dengan Munandar (1985) bahwa peran wanita bukan hanya bekerja di dalam rumah tangga yaitu melayani, Tetapi juga melakukan kegiatan yang memberikan penghasilan untuk kebutuhan keluarga. Sama halnya dengan Jane (1991:65) mengungkapkan bahwa dalam masyarakat dimana keluarga sebagai satuan terkecil mengalami kekurangan ekonomi, menjadi alasan kuat para perempuan melakukan peningkatan ekonomi dengan melakukan kegiatan ekonomi dan menambah penghasilan. Oleh karenanya hal tersebut lah yang mendorong para istri (kaum ibu) untuk melakukan tindakan yang berguna dalam memenuhi kebutuhan keluarganya.

Berdasarkan wawancara dengan istri (ibu) tentang pendapatan keluarga, mereka hanya mengandalkan pendapatan suami yang rata-rata dari hasil buruh tani hanya memperoleh $\mathrm{Rp}$ 50.000-60.000/hari. Sedangkan suami yang bekerja sebagai buruh perkebunan rata-rata memperoleh Rp 80.000-100.000/hari. Jika dihitung perbulannya itu tidak mencukupi untuk memenuhi kebutuhan hidup mereka, dengan banyaknya kebutuhan yang harus dipenuhi oleh keluarga.

Usaha untuk mengatasi sulitnya perekonomian keluarga, maka suami-istri bekerja bersamasama mencari tambahan pendapatan. Ternyata peran istri dalam menunjang perekonomian rumah tangga sangat besar. Dari penelitian ini terlihat bahwa para istri memiliki tugas yang sifatnya multifungsi, tidak hanya melaksanakan peran dan kedudukannya didalam rumah tangga tetapi mempunyai peran dan kedudukan diluar keluarga dengan bekerja tambahan membuka warung, mencari sapu lidi, menanam sayur, menjadi buruh perkebunan. Dari hasil pengamatan dapat dilihat bahwa penghasilan istri yang mencari tambahan, kalau hanya mencari sapu lidi sekitar Rp 400.000/perbulan, warung kecil-kecilan Rp 1000.0001.500.000/perbulan, buruh perkebunan yang pendapatnnya lebih banyak sekitar $\mathrm{Rp}$ $1500.000 /$ perbulan

Dengan memahami kegiatan para istri petani keseluruhannya, dapat dilihat tidak ada lagi waktu luang bagi para istri-ibu untuk bersantai, mereka harus memikirkan bagaimana bisa berperan diranah domestik dan publik. 


\section{Dampak Peran Wanita dalam Kehidupan Perekonomian rumah tangga di Dusun Pulau Intan.}

Para wanita yang bekerja diluar rumah ternyata mereka bekerja tidak melupakan tanggung jawabnya sebagi seorang istri dan ibu. Mereka tetap dapat membagi waktu dan kesempatan dalam dua perannya. Sedangkan suami hanya fokus bekerja mencari nafkah kalau pun memikirkan urusan rumah tangga menyangkut masalah yang kompleks saja. Oleh karena itu jika dilihat dari beban tanggungjawab, ternyata istri-ibu lebih besar bebannya jika dibandingkan dengan suami. Hal ini dapat dilihat bagamimana para istri-ibu berusaha memenuhi kebutuhan ekonomi rumah tangga mereka.

Berdasarkan hasil pengamatan dapat dilihat bahwa penghasilan istri yang mencari tambahan, kalau hanya mencari sapu lidi sekitar Rp 400.000/perbulan, warung kecilkecilan Rp 1.500.000/perbulan, buruh perkebunan sekitar Rp1.500.000/ perbulan. Jika dilihat dari perolehan pendapatan istri-ibu memang tidak begitu besar akan tetapi sangat memberikan dampak pada kehidupan perekonomian rumah tangganya.

Berdasarkan hasil pengamatan dan wawancara, ternyata wanita (istri-ibu) di Dusun Pulau Intan peran yang mereka lakukan memberi dampak yang sangat besar, baik dalam pendapatan, pengelolaan keuangan dan mengurusi pekerjaan rumah tangga.

\section{KESIMPULAN}

1. Peran aktif wanita sebagai istri-ibu rumah tangga di Dusun Pulau Intan Kecamatan pangkatan kabupaten Labuhanbatu sangat besar, karena istri mempunyai dua peran ganda selain beban kerja didalam rumah tangga, juga berperan sebagi pekerja diluar rumah.

2. Dampak peran aktif wanita (istri-ibu) di Dusun Pulau Intan dalam perekonomiannya sangat tinggi. Mereka bisa memberikan sumbangsih yang besar bagi pendapatan keluarga, walaupun pendapatannya tidak terlalu besar tapi sangat berdampak postif bagi perekonomian keluarga

\section{DAFTAR PUSTAKA}

Darmawani. 2013. Peran perempuan dalam meningkatkan perekonomian keluarga. Skripsi. Fakultas Ilmu Sosial dan Ilmu Politik Universitas Teuku Umar

Jume'edi (2005) Peran wanita dalam meningkatkan pendapatan keluarga nelayan di kelurahan ujung Batu, Kecamatan Jepara, Kabupaten Jepara. Tesis S2 Program Pascasarjana Universitas Diponegoro

Kirnoprasetyo, Istiyono (2007) peranan wanita tani dalam perekonomian keluarga petani di pedesaan (utopia, konseptual, dan realita. Jurnal Primordia, vol 3, No 1

Kementrian Sosial, BPS. 2012). Analisis data kemiskinan berdasarkan data pendapatan program perlindungan sosial program perlindungan sosial (PPLS) 2011. Jakarta: Kementrian Sosial Republik Indonesia

Mariun, N.Badrun. 2004. Kontribusi Perempuan pada Peningkatan Pendapatan Rumah Tangga Miskin: Studi Kasus di 4 Kabupaten/Kota. Warta Demografi Tahun 34 No.3 
Yuniarti, Sari dan Haryanto, sugeng.2005. Pekerja wanita pada industri Rumah Tangga Sandang dan Kontribusinya Terhadap Pendapatan Rumah Tangga di Kecamatan Sukun Malang. Jurnal Universitas Merdeka Malang Vol XVII Nomor 2 Tahun 200. 